\title{
Ecological risk assessment of metals contamination in the sediment of the Bamdezh wetland, Iran
}

\author{
A. R. Vaezi $\cdot$ A. R. Karbassi $\cdot$ Sh. Valavi \\ M. R. Ganjali
}

Received: 4 August 2014/Revised: 11 October 2014/ Accepted: 1 November 2014/Published online: 18 December 2014

(C) Islamic Azad University (IAU) 2014

\begin{abstract}
Present survey investigates the intensity of heavy metals pollution ( $\mathrm{Ca}, \mathrm{Fe}, \mathrm{Ni}, \mathrm{Cd}, \mathrm{Pb}, \mathrm{Zn}, \mathrm{AS}, \mathrm{Hg}$ ) in the sediments of Bamdezh wetland, Iran. The main objective of the study is quantification of heavy metal pollution intensity in this wetland. Bamdezh wetland is located in about $40 \mathrm{~km}$ northwest of Ahvaz, Iran. This wetland is a habitat and food source for aquatic ecosystem and migratory birds, also a significant resource of income for the locals. Anthropogenic portion of the metals was determined through five-step chemical sequential extraction. The results of partition studies revealed the arrangement of anthropogenic portions for the metals as follows: $\mathrm{Cd}(86 \%)>\mathrm{Pb}(80 \%)>\mathrm{Ni}(46 \%)>\mathrm{Zn}(44 \%)>\mathrm{Fe}$ $(24 \%)$. The mean enrichment factor values for various metals were between minimal enrichment and extremely enrichment. The values obtained from $I_{\text {poll }}$ index are indicative of a broad range from unpolluted to moderately polluted to moderately to strongly polluted. All stations can be interpreted as a very high degree of contamination using $C_{\mathrm{d}}$ and high degree of contamination using $\mathrm{mC}_{\mathrm{d}}$ classification. PLI ranged from 1.22 at station 3 to 1.55 at station 4. Result of cluster analysis for $\mathrm{Zn}$ and LOI shows that these two elements are related together by high similarity
\end{abstract}

A. R. Vaezi · A. R. Karbassi ( $\square)$

Graduate Faculty of Environment, University of Tehran,

\#23, Azin Avenue, Ghods Street, Enghelab Square, 1417853111 Tehran, Iran

e-mail: arkarbassi738@yahoo.com; akarbasi@ut.ac.ir

\section{Sh. Valavi}

Department of Environmental Sciences, Faculty of Environment, IA University, Ahvaz, Iran

M. R. Ganjali

Faculty of Chemistry, Center of Excellence in Electrochemistry,

University of Tehran, Tehran, Iran coefficient. As LOI in the environment is the index of biological activity, then $\mathrm{Zn}$ should have biological origin. The dendrogram also showed that a part of $\mathrm{Ca}$ and $\mathrm{Ni}$ is derived from lithogenous source as they are linked to Fe.

Keywords Bamdezh wetland A Anthropogenic proportion $\cdot$ Sediment contamination $\cdot$ Metal pollution

\section{Introduction}

Heavy metals possess toxicological role in marine ecosystem. Accumulation of trace metals in aquatic system and sediments depends on different factors such as the nature of sediment particles and factors that affect physicochemical conditions (Nemr et al. 2007). We can obtain useful information about aquatic systems by studying heavy metals in surficial sediments (Förstner and Wittmann 1981). In the recent, more attention has been paid to the aquatic pollution; however, most of the studies aim at metal pollution (Lee and Mohamed 2009; Al-Juboury 2009; Uba et al. 2009; Venugopal et al. 2009). The most crucial properties of metals are that they are not biodegradable (Ahmed et al. 2010; Sundararajan and Natesan 2010; Adjey-Boateng et al. 2010; Rafiei et al. 2010). Marine sediments can bring out the aquatic contamination (Sinem Atgin et al. 2000).

Sediment-bound heavy metals may be desorbed from surface sediment and accumulated on fine-grained particles which finally move into the depositional (Karbassi et al. 2014). Grain size is an important factor to evaluate heavy metals concentration in the sediment (Szefer et al. 1996).

Inputs of heavy metals and other pollutants to the coastal areas are likely increasing because of economic growth in Asian countries (Nasehi et al. 2012). Heavy 
metals and petroleum hydrocarbons are considered as a common environmental contamination and a worldwide concern (Valikhani Samani et al. 2014). The chemical bonds of metals in marine sediments are important factors in assessing pollution in a different phase of the aquatic environment. (Tessier et al. 1979; Förstner and Wittmann 1981).

According to the International Ramsar Convention declaration, the Bamdezh wetland is riverine and palustrine wetland. Bamdezh wetland is suitable ecosystem for fish of fresh water, suitable place for birds and creates microclimate that cause increasing relative humidity and decreasing temperature. In addition, this wetland has important role to control over flow of Dez and Shavour rivers. This wetland is a habitat and food source for aquatic ecosystem and migratory birds, and also a significant resource of income for the locals. Inputs of various source of pollutants to the wetland areas are increasing because of economic growth. Therefore, water depth and wetland life have been threatened. The land use of study area are divided to agricultural land, fish ponds and residential area. The significant portions of the area surrounding the Bamdezh wetland are Barren lands (Bostanzadeh 2003).

Current study was performed in Bamdezh wetland, which is located in about $40 \mathrm{~km}$ northwest of Ahvaz, Iran. The aim of this study was to determine sediment contamination and ecological risk assessments in the Bamdezh wetland, Iran. Subsequently, various indices were used to show the intensity of pollution in this area.

\section{Materials and methods}

\section{Sampling area}

Bamdezh wetland is a part of Khuzestan province, situated in southwestern Iran, between longitudes $48^{\circ} 27^{\prime}-48^{\circ} 42^{\prime} \mathrm{E}$ and latitudes $31^{\circ} 38^{\prime}-31^{\circ} 55^{\prime} \mathrm{N}$. The wetland area is about 44 square kilometers. Bamdezh wetland is a natural and freshwater in this wetland is mainly due to water of Shavour River. The outlet of this wetland is Kharoor that pass of Tavana Channel and finally discharge to Dez River (Jamee 2002).

Pollutants which currently intimidate flora and fauna of Bamdezh wetland and are expected to exacerbate its future condition can be categorized in two major types, including:

1. Agricultural pollutants: This group involves animal fertilizers and pesticides enter the wetland from farms surrounding it or from input water being polluted in its path toward this water body.

2. Industrial, rural and urban Pollutants: These types of pollutants originate from the sewage of villages in the vicinity of wetland and contaminated input water with industrial and urban effluents. The sewage of Shoush city, livestock in the way of inputs, sewage and suspended solid wastes of Shavour region are all carried along with the Shavour River and reach the wetland.

Surface sediment samples were collected from six sites in Bamdezh wetland (Fig. 1). Locations of sampling stations in Bamdezh wetland were determined by the aid of Global Positioning System (GPS) (Table 1).

Samples for metal analysis are prepared according to MOOPAM. They were collected using a zinc-plated Peterson grab. A Teflon spatula was used to extract the sediment samples from the center of grab. After collecting samples, the surface sediment samples were immediately

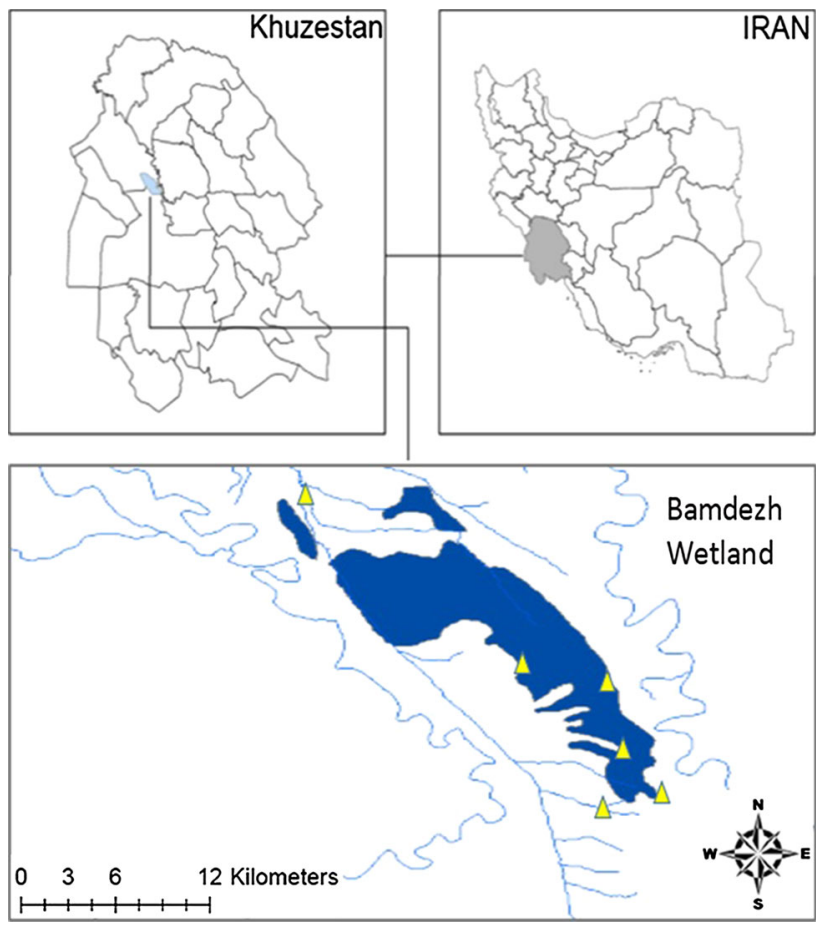

Fig. 1 Location of the study area showing sampling points

Table 1 General features and description of coastal sampling sites of Bamdezh wetland

\begin{tabular}{lllll}
\hline St. no. & N & E & $\begin{array}{l}\text { Water } \\
\text { temperature C }\end{array}$ & $\begin{array}{l}\text { Air } \\
\text { temperature C }\end{array}$ \\
\hline St1 & $31^{\circ} 49^{\prime} 54^{\prime \prime}$ & $48^{\circ} 27^{\prime} 15.8^{\prime}$ & 24 & 30 \\
St2 & $31^{\circ} 45^{\prime} 40.5^{\prime \prime}$ & $48^{\circ} 34^{\prime} 4.4^{\prime \prime}$ & 26 & 31 \\
St3 & $31^{\circ} 45^{\prime} 04.2^{\prime \prime}$ & $48^{\circ} 36^{\prime} 1^{\prime \prime}$ & 26 & 31 \\
St4 & $31^{\circ} 42^{\prime} 24.2^{\prime \prime}$ & $48^{\circ} 35^{\prime} 43.9^{\prime}$ & 26 & 31 \\
St5 & $31^{\circ} 41^{\prime} 43.5^{\prime \prime}$ & $48^{\circ} 38^{\prime} 32.1^{\prime \prime}$ & 29 & 30 \\
St6 & $31^{\circ} 39^{\prime} 33.9^{\prime \prime}$ & $48^{\circ} 38^{\prime} 39.1^{\prime \prime}$ & 26 & 39 \\
\hline
\end{tabular}


packed in airtight pre-labeled polyethylene bags and preserved at $4{ }^{\circ} \mathrm{C}$ till the metal analysis. Grain size fractions less than $63 \mu \mathrm{m}$ were separated for geochemical analysis (Vaezi et al. 2014).

\section{Chemical analysis}

The concentration of elements $(\mathrm{Ca}, \mathrm{Fe}, \mathrm{Ni}, \mathrm{Cd}, \mathrm{Pb}, \mathrm{Zn}, \mathrm{AS}$, $\mathrm{Hg}$ ) in sediment samples was determined by atomic absorption spectroscopy (Varian AA-30 model).

All the sediment samples were gently air-dried at $50{ }^{\circ} \mathrm{C}$ and then sieved. The sediments were weighted and placed into a Teflon beaker and were digested using $7 \mathrm{~mL}$ of aqua regia $\left(1: 3 \mathrm{HCl}: \mathrm{HNO}_{3}\right)$. The mixture heated at $95{ }^{\circ} \mathrm{C}$ for $1 \mathrm{~h}$ and refluxed for $5-10 \mathrm{~min}$ until the brown fumes were no longer visible, and after cooling, $5 \mathrm{~mL}$ of hydrogen fluoride (HF) was added. Then, samples were refluxed to room temperature. Sediment samples were filtered by Whatman $0.45 \mu \mathrm{m}$ membrane and brought to $50 \mathrm{~mL}$ volume using $1 \mathrm{~N} \mathrm{HCl}$ (Karbassi et al. 2008).

Organic matters were measured by recording the loss on ignition (LOI) through heating the samples for $4 \mathrm{~h}$ at $450{ }^{\circ} \mathrm{C}$ in a muffle furnace. The organic contents range from 5.97 to $19.06 \%$ with a mean value of $14.88 \%$. To obtain bioaccessibility values, a solution of $\mathrm{pH}=5$ was prepared using $\mathrm{NaOH}$ and HOAc (USEPA, 1311 method).

Finally, the origination of metals was investigated. Heavy metals have five kind of bonds so in this study, following five operational steps were used for chemical extraction.

The chemical partitioning of metals was determined by means of the sequential extraction scheme proposed by Tessier et al. (1979) and modified by Elsokkary and Muller (1990). Fraction I (exchangeable): About $1 \mathrm{~g}$ of each sediment sample was shaken for $60 \mathrm{~min}$ at room temperature with $8 \mathrm{ml}$ of $1 \mathrm{M}\left(\mathrm{MgCl}_{2} \cdot 6 \mathrm{H}_{2} \mathrm{O}\right)$.

Fraction II (bound to carbonates): The residual solid of each sediment sample from step I was shaken for about $30 \mathrm{~min}$ at room temperature with $8 \mathrm{ml}$ of $1 \mathrm{M}\left(\mathrm{C}_{2} \mathrm{H}_{3} \mathrm{NaO}_{2}\right)$ and adjusted to $\mathrm{pH} 5.0$ with $\left(99.83 \% \mathrm{C}_{2} \mathrm{H}_{4} \mathrm{O}_{2}\right)$.

Fraction III (bound to iron and manganese oxides: (reducible): The residual solid of each sediment sample from step II was shaken at $85 \mathrm{oC}$ in water bath for about $5 \mathrm{~h}$ with $20 \mathrm{ml}$ of $0.04 \mathrm{M}\left(\mathrm{H}_{3} \mathrm{NO} \cdot \mathrm{HCl}\right)$ in $25 \%(99.83 \%$ $\left.\mathrm{C}_{2} \mathrm{H}_{4} \mathrm{O}_{2}\right)(\mathrm{v} / \mathrm{v})$.

Fraction IV (bound to organic and sulfide): The residual solid of each sediment sample from step III was shaken at $85 \mathrm{oC}$ in a water bath for about $2 \mathrm{~h}$ with $5 \mathrm{ml}$ of $(30 \%$ $\mathrm{H}_{2} \mathrm{O}_{2}$ ). Nitric acid was added to reach the $\mathrm{pH}$ of samples to $2 \pm 0.2$. Subsequently, a second addition of $3 \mathrm{ml}$ of $30 \%$ $\mathrm{H}_{2} \mathrm{O}_{2}$ was added and the samples were shaken again at $85 \mathrm{oC}$ in a water bath for $3 \mathrm{~h}$.
Fraction V (residual): Finally, the residual solid of each sediment sample from step IV was digested with a mixture of $\mathrm{HNO}_{3}, \mathrm{HF}, \mathrm{HClO}_{4}, \mathrm{HCl}$ in $(4: 1: 1: 1)$ ratio, respectively, for about $3 \mathrm{~h}$ in a water bath.

In each step, the supernatant was filtered by Whatman $0.45 \mu \mathrm{m}$ membrane, and the residue was shaken with $8 \mathrm{ml}$ of deionized water for about $30 \mathrm{~min}$.

\section{Quality assurance/quality control (QA/QC)}

In accordance to the quality assurance program, procedural blanks, duplicates and MESS-1, standard sediment samples were run alongside the sediment samples. The accuracy of analysis was about $\pm 4 \%$ for all elements.

\section{Data analysis}

Pollution assessment and evaluation were carried out using several techniques including: enrichment factor (EF), geoaccumulation index $\left(I_{\mathrm{geo}}\right)$, pollution index $\left(I_{\mathrm{POOL}}\right)$, contamination factor $\left(C_{\mathrm{f}}\right)$, modified degree of contamination $\left(\mathrm{mC}_{\mathrm{d}}\right)$ and pollution load index (PLI).

\section{Results and discussion}

Descriptive statistics of the metals concentration for the Bamdezh wetland including mean, maximum, minimum and shale values, and also standard deviation all are shown in Table 2 :

As shown in Table 2, there is a significant difference between mean concentration of $\mathrm{Hg}$ and the correspondent shale value. The results revealed that the concentration of $\mathrm{Fe}$ is between 3.74 and $5.24 \mathrm{mg} / \mathrm{kg}$ with the mean value of $4.32 \mathrm{mg} /$ $\mathrm{kg}$. The maximum concentration of $\mathrm{Ni}$ was found at the station 5. The concentration of Cd range from 9.67 to $16.65 \mathrm{mg} / \mathrm{kg}$ with a mean value of $14.21 \mathrm{mg} / \mathrm{kg}$. Also, the organic contents range from 5.97 to $19.06 \%$ with a mean value of $14.88 \%$.

The results of chemical partitioning are presented in Table 3. The results of chemical partitioning studies have revealed the arrangement of natural portions for the metals as follows: $\mathrm{Cd}(86 \%)>\mathrm{Pb}(80 \%)>\mathrm{Ni}(46 \%)>\mathrm{Zn}$ $(44 \%)>\mathrm{Fe}(24 \%)$. Percentage of natural and anthropogenic sections of studied heavy metals shows that $\mathrm{Cd}$ and $\mathrm{Pb}$ pollution is mostly from anthropogenic origin, and $\mathrm{Fe}$, $\mathrm{Zn}$ and $\mathrm{Ni}$ are mostly from natural origin. Although a high proportion of $\mathrm{Ca}$ is released in the first phase of chemical analysis (loose part), this fact does not show that this is a consequence of anthropogenic pollution. Step 1 and step 2 show the greatest degree of metal mobility. Step 3 and step 4 exhibit some degree of mobility, and the step 5 corresponds to the part of the metals that cannot be mobilized.

Metal enrichment factor (EF) was used in ecotoxicological and chemo-ecological assessment by Buat-Menard 
Table 2 Elemental concentration of surficial sediments of Bamdezh wetland

\begin{tabular}{|c|c|c|c|c|c|c|c|c|c|}
\hline Station number & $\begin{array}{l}\text { As } \\
(\mathrm{mg} / \mathrm{kg})\end{array}$ & $\mathrm{Cd}$ & $\mathrm{Hg}$ & $\mathrm{Ni}$ & $\mathrm{Pb}$ & $\mathrm{Zn}$ & $\begin{array}{l}\mathrm{Ca} \\
(\%)\end{array}$ & $\mathrm{Fe}$ & LOI \\
\hline 1 & 4.16 & 13.50 & 4.83 & 99.50 & 22.12 & 40.00 & 1.10 & 3.80 & 12.07 \\
\hline 2 & 3.26 & 9.67 & 5.28 & 86.00 & 17.36 & 80.00 & 0.91 & 4.41 & 17.22 \\
\hline 3 & 3.22 & 15.69 & 2.79 & 47.00 & 32.13 & 44.50 & 0.90 & 3.74 & 5.97 \\
\hline 4 & 5.02 & 16.65 & 5.48 & 74.25 & 18.48 & 87.50 & 1.12 & 4.20 & 18.57 \\
\hline 5 & 2.89 & 16.12 & 1.63 & 124.75 & 18.62 & 70.00 & 1.19 & 5.24 & 16.41 \\
\hline 6 & 3.68 & 13.61 & 4.30 & 89.50 & 21.56 & 57.00 & 1.00 & 4.51 & 19.06 \\
\hline Min & 2.89 & 9.67 & 1.63 & 47.00 & 17.36 & 40.00 & 0.90 & 3.74 & 5.97 \\
\hline Max & 5.02 & 16.65 & 5.48 & 124.75 & 32.13 & 87.50 & 1.19 & 5.24 & 19.06 \\
\hline Mean & 3.71 & 14.21 & 4.05 & 86.83 & 21.71 & 63.17 & 1.04 & 4.32 & 14.88 \\
\hline Mean crust ${ }^{\mathrm{a}}$ & 13 & 0.3 & 1.4 & 80 & 14 & 75 & 4.1 & 4.1 & - \\
\hline
\end{tabular}

${ }^{a}$ Bowen (1979)

and Chesselet (1979). The EF of all elements can be calculated using the following equation (Zhang et al. 2007).

$\mathrm{EF}=\left(\left[\left(M_{\mathrm{c}}\right) /\left(M_{\mathrm{r}}\right)\right]_{\mathrm{s}}\right) /\left(\left[\left(M_{\mathrm{c}}\right) /\left(M_{\mathrm{r}}\right)\right]_{\mathrm{b}}\right)$

where $M_{\mathrm{c}}$ is the concentration of metals, $M_{\mathrm{r}}$ is the concentration of reference elements, $s$ is the studied sample and b indicates the background. This method uses a normalization element such as $\mathrm{Al}$ or Fe to alleviate the variations caused by heterogeneous sediments (Abrahim and Parker 2008). Five contamination categorizes are recognized based on EF value (Sutherland 2000; Loska and Wiechuła 2003):

1. $\mathrm{EF}<2$ Depletion to minimal enrichment suggestive of no or minimal pollution.

2. EF 2-5 Moderate enrichment, suggestive of moderate pollution.

3. EF 5-20 Significant enrichment, suggestive of a significant pollution signal.

4. EF 20-40 Very highly enrichment, indicating a very strong pollution signal.

5. EF $>40$ Extremely enrichment, indicating an extreme pollution signal.

The obtained mean enrichment factor $(\mathrm{EF})$ values for various metals were between minimal enrichment and extremely enrichment. The maximum mean $\mathrm{EF}$ value belongs to $\mathrm{Cd}(\mathrm{Cd}=45.55)$ indicating extremely enrichment, and also, the minimum mean EF value is seen for As (As $=0.28)$ showing minimal enrichment (Table 4).

In order to determine the degree of contamination in each sediment, geo-accumulation index value is calculated using the following equation (Muller 1979; Zhuang and Gao 2014):

$I_{\text {geo }}=\log _{2}\left(\frac{C_{n}}{1.5 B_{n}}\right)$

where $C_{n}$ is the content of metals in sediment samples, and $B_{n}$ is the geochemical background concentration for each element. A constant equal to 1.5 is defined to take the possible lithological variability into account (Abrahim and Parker 2008). Muller's formula was modified by Karbassi et al. (2008) as follows:

$I_{\mathrm{POLL}}=\log _{2}\left(\frac{B_{n}}{L_{\mathrm{p}}}\right)$

where $B_{n}$ and $L_{\mathrm{p}}$ represent bulk concentration and lithogenous portion, respectively, the geo-accumulation index and the pollution index have seven classes (Table 5).

The degree of sediment contamination was calculated using Muller's index. Further, newly developed pollution index developed by Karbassi et al. (2008) called as $I_{\text {poll }}$ was used to assess the degree of pollution (Table 6).

The results of geo-accumulation index $\left(I_{\text {geo }}\right)$ of metals for sediment samples show the limitation of $I_{\text {geo }}$ index in the assessment of pollution. The values of geo-accumulation index are less than 0 for all element except for $\mathrm{Cd}$ (4.98). The values obtained from $I_{\text {poll }}$ index are indicative of a broad range (from unpolluted to moderately polluted to moderately to strongly polluted) for various studied elements.

Integrated indices are indicators used to calculate more than one metal contamination, which were based on the single indices (PLI, $C_{\mathrm{d}}$ and $\mathrm{mC}_{\mathrm{d}}$ ). The contamination factor $\left(C_{\mathrm{f}}\right)$, defined by Hakanson (1980), is obtained by dividing the concentration of each element in the sediment sample by background concentration in unpolluted sediment:

$C_{\mathrm{f}}=\frac{C_{\text {metal }}}{C_{\text {background }}}$

The overall degree of contamination is defined as follows:

$C_{\mathrm{d}}=\sum_{i=1}^{n} C_{\mathrm{f}}^{i}$

$C_{\mathrm{f}}$ and $C_{\mathrm{d}}$ were classified into seven classes (Table 7). 
Table 3 Specification of heavy metals in Bamdezh wetland sediments

\begin{tabular}{|c|c|c|c|c|c|c|c|c|c|}
\hline \multirow[t]{2}{*}{ Metals } & \multirow[t]{2}{*}{ Stations } & \multirow[t]{2}{*}{ Bioavailable } & \multicolumn{5}{|c|}{ Fractional steps } & \multirow{2}{*}{$\begin{array}{l}\text { Anthropogenic } \\
\text { portion }(\mathrm{mg} / \mathrm{kg})\end{array}$} & \multirow{2}{*}{$\begin{array}{l}\text { Lithogenous } \\
\text { portion }(\mathrm{mg} / \mathrm{kg})\end{array}$} \\
\hline & & & Step1 & Step2 & Step3 & Step4 & Step5 & & \\
\hline \multirow[t]{7}{*}{$\mathrm{Ca}(\%)$} & St1 & 0.07 & 0.30 & 0.19 & 0.22 & 0.33 & 0.00 & 0.78 & 0.33 \\
\hline & St2 & 0.05 & 0.25 & 0.20 & 0.15 & 0.26 & 0.00 & 0.65 & 0.26 \\
\hline & St3 & 0.07 & 0.09 & 0.32 & 0.09 & 0.34 & 0.00 & 0.56 & 0.34 \\
\hline & St 4 & 0.17 & 0.22 & 0.35 & 0.17 & 0.21 & 0.00 & 0.91 & 0.21 \\
\hline & St5 & 0.09 & 0.25 & 0.27 & 0.33 & 0.25 & 0.00 & 0.94 & 0.25 \\
\hline & St6 & 0.05 & 0.20 & 0.23 & 0.22 & 0.30 & 0.00 & 0.70 & 0.31 \\
\hline & Mean & 0.08 & 0.22 & 0.26 & 0.20 & 0.28 & 0.00 & 0.76 & 0.28 \\
\hline \multirow[t]{7}{*}{$\mathrm{Fe}(\%)$} & St1 & 0.01 & 0.46 & 0.45 & 0.00 & 2.85 & 0.00 & 0.92 & 2.85 \\
\hline & St2 & 0.00 & 0.62 & 0.23 & 0.00 & 3.55 & 0.00 & 0.86 & 3.55 \\
\hline & St3 & 0.01 & 0.34 & 0.24 & 0.01 & 3.15 & 0.00 & 0.60 & 3.15 \\
\hline & St4 & 0.01 & 0.33 & 0.29 & 0.00 & 3.55 & 0.00 & 0.64 & 3.56 \\
\hline & St5 & 0.01 & 0.46 & 0.20 & 0.12 & 3.36 & 0.00 & 1.87 & 3.36 \\
\hline & St6 & 0.01 & 0.30 & 0.26 & 0.65 & 3.29 & 0.00 & 1.22 & 3.30 \\
\hline & Mean & 0.01 & 0.42 & 0.28 & 0.13 & 3.29 & 0.00 & 1.02 & 3.30 \\
\hline \multirow[t]{7}{*}{ Zn (mg/kg) } & St1 & 2.50 & 11.50 & 8.50 & 4.50 & 11.00 & 2.00 & 27.00 & 13.00 \\
\hline & St2 & 2.00 & 12.00 & 10.50 & 3.00 & 51.00 & 1.50 & 27.50 & 52.50 \\
\hline & St3 & 3.00 & 10.00 & 9.50 & 2.00 & 19.00 & 1.00 & 24.50 & 20.00 \\
\hline & St4 & 3.50 & 8.00 & 11.00 & 4.00 & 56.50 & 4.50 & 26.50 & 61.00 \\
\hline & St5 & 2.00 & 12.00 & 9.50 & 5.50 & 38.50 & 2.50 & 29.00 & 41.00 \\
\hline & St6 & 3.00 & 13.00 & 9.00 & 5.50 & 24.00 & 2.50 & 30.50 & 26.50 \\
\hline & Mean & 2.67 & 11.08 & 9.67 & 4.08 & 33.33 & 2.33 & 27.50 & 35.67 \\
\hline \multirow[t]{7}{*}{$\mathrm{Cd}(\mathrm{mg} / \mathrm{kg})$} & St1 & 2.37 & 1.57 & 5.47 & 1.88 & 2.17 & 0.04 & 11.29 & 2.21 \\
\hline & St2 & 2.12 & 1.57 & 3.01 & 0.82 & 2.11 & 0.04 & 7.52 & 2.15 \\
\hline & St3 & 2.21 & 0.16 & 9.61 & 1.56 & 2.10 & 0.05 & 13.54 & 2.20 \\
\hline & St4 & 6.57 & 5.75 & 2.76 & 0.40 & 1.14 & 0.03 & 15.48 & 1.17 \\
\hline & St5 & 2.17 & 2.17 & 7.68 & 2.05 & 2.02 & 0.03 & 14.07 & 2.05 \\
\hline & St6 & 2.44 & 0.76 & 7.50 & 0.92 & 1.95 & 0.04 & 11.62 & 1.99 \\
\hline & Mean & 2.98 & 2.00 & 6.01 & 1.27 & 1.92 & 0.04 & 12.25 & 1.96 \\
\hline \multirow[t]{7}{*}{$\mathrm{Pb}(\mathrm{mg} / \mathrm{kg})$} & St1 & 0.98 & 8.40 & 5.74 & 1.47 & 4.90 & 0.63 & 16.59 & 5.53 \\
\hline & St2 & 0.14 & 7.21 & 4.55 & 1.05 & 3.85 & 0.56 & 12.95 & 4.41 \\
\hline & St3 & 1.19 & 18.90 & 5.81 & 1.96 & 3.92 & 0.35 & 27.86 & 4.27 \\
\hline & St4 & 0.70 & 6.02 & 5.18 & 2.03 & 3.99 & 0.56 & 13.93 & 4.55 \\
\hline & St5 & 0.14 & 7.28 & 6.37 & 0.98 & 3.64 & 0.21 & 14.77 & 3.81 \\
\hline & St6 & 0.28 & 7.91 & 6.86 & 2.52 & 3.78 & 0.21 & 17.57 & 3.99 \\
\hline & Mean & 0.57 & 9.29 & 5.75 & 1.67 & 4.01 & 0.42 & 17.28 & 4.43 \\
\hline \multirow[t]{7}{*}{ Ni (mg/kg) } & St1 & 4.75 & 15.25 & 7.25 & 2.00 & 69.50 & 0.75 & 29.25 & 70.25 \\
\hline & St2 & 3.50 & 15.75 & 3.50 & 5.25 & 57.00 & 1.00 & 28.00 & 58.00 \\
\hline & $\mathrm{St} 3$ & 1.50 & 16.75 & 6.75 & 1.25 & 19.25 & 1.50 & 26.25 & 20.75 \\
\hline & St4 & 3.00 & 7.50 & 6.75 & 2.50 & 53.75 & 0.75 & 19.75 & 54.50 \\
\hline & St5 & 3.25 & 50.00 & 11.50 & 17.00 & 42.00 & 1.00 & 81.75 & 43.00 \\
\hline & St6 & 1.50 & 25.50 & 13.75 & 17.00 & 29.50 & 2.25 & 57.75 & 31.75 \\
\hline & Mean & 2.92 & 21.79 & 8.25 & 7.50 & 45.17 & 1.21 & 40.46 & 46.37 \\
\hline
\end{tabular}

The modified degree of contamination $\left(\mathrm{mC}_{\mathrm{d}}\right)$ was proposed by Abrahim and Parker (2008) as follows:

$\mathrm{mC}_{\mathrm{d}}=\frac{\sum_{i=1}^{n} C_{\mathrm{f}}^{i}}{n}$
The modified degree of contamination consists of seven classes (Table 8).

Pollution load index (PLI) was employed by Tomlinson et al. (1980) to evaluate the extent of the contamination by 
Table 4 Enrichment factors (EF) of metals for sediment samples

\begin{tabular}{llllllll}
\hline Station number & $\mathrm{As}$ & $\mathrm{Cd}$ & $\mathrm{Hg}$ & $\mathrm{Ni}$ & $\mathrm{Pb}$ & $\mathrm{Zn}$ & $\mathrm{Ca}$ \\
\hline 1 & 0.40 & 55.66 & 4.27 & 1.81 & 1.37 & 0.52 & 0.62 \\
2 & 0.27 & 34.35 & 4.02 & 1.35 & 0.93 & 0.90 & 0.44 \\
3 & 0.31 & 65.72 & 2.50 & 0.87 & 2.02 & 0.59 & 0.51 \\
4 & 0.43 & 62.11 & 4.38 & 1.22 & 1.03 & 1.03 & 0.57 \\
5 & 0.20 & 48.20 & 1.04 & 1.65 & 0.84 & 0.66 & 0.49 \\
6 & 0.30 & 47.28 & 3.20 & 1.37 & 1.12 & 0.63 & 0.47 \\
Mean EF & 0.32 & 52.22 & 3.24 & 1.38 & 1.22 & 0.72 & 0.52 \\
\hline
\end{tabular}

Table 5 Contamination categories based $I_{\text {geo }}$ and $I_{\text {poll }}$ values

\begin{tabular}{ll}
\hline$I_{\text {geo }}$ & Description \\
\hline$>5$ & Extremely polluted \\
$4-5$ & Strongly to extremely strongly polluted \\
$3-4$ & Strongly polluted \\
$2-3$ & Moderately to strongly polluted \\
$1-2$ & Moderately polluted \\
$0-1$ & Unpolluted to moderately polluted \\
$<0$ & Unpolluted \\
\hline
\end{tabular}

Table 6 Anthropogenic and natural portions of metals and $I_{\text {poll }}$ (Pollution Index) of surficial sediments

\begin{tabular}{lllllll}
\hline Elements & $\mathrm{Ca}$ & $\mathrm{Fe}$ & $\mathrm{Zn}$ & $\mathrm{Cd}$ & $\mathrm{Pb}$ & $\mathrm{Ni}$ \\
\hline $\begin{array}{l}\text { Mean concentration } \\
(\mathrm{mg} / \mathrm{kg})\end{array}$ & 1.04 & 4.32 & 63.17 & 14.21 & 21.71 & 86.83 \\
$\begin{array}{c}\text { Anthropogenic } \\
\text { portion (mg/kg) }\end{array}$ & 0.76 & 1.02 & 27.5 & 12.25 & 17.28 & 40.46 \\
$\begin{array}{c}\text { Lithogenous portion } \\
(\mathrm{mg} / \mathrm{kg})\end{array}$ & 0.28 & 3.30 & 35.67 & 1.96 & 4.43 & 46.37 \\
$\begin{array}{c}\text { Anthropogenic } \\
\text { portion (\%) }\end{array}$ & 73.08 & 23.61 & 43.53 & 86.21 & 79.59 & 46.60 \\
$\begin{array}{c}\text { Lithogenous portion } \\
(\%)\end{array}$ & 26.92 & 76.39 & 56.47 & 13.79 & 20.41 & 53.40 \\
\begin{tabular}{l}
$I_{\text {poll }}$ \\
\hline
\end{tabular} & 1.89 & 0.39 & 0.82 & 2.86 & 2.29 & 0.91 \\
\hline
\end{tabular}

metals in marine sediments. PLI was calculated using the following equation:

PLI $=\left(C f_{1} \times C f_{2} \times C f_{3} \times \cdots \times C f_{n}\right)^{(1 / n)}$

where $C_{\mathrm{f}}$ is the contamination factor, and $\mathrm{n}$ is the number of metals, PLI $>1$ indicates pollution, whereas PLI $<1$ indicates no pollution.
Table 7 Terminologies used to describe $C_{\mathrm{f}}$ and $C_{\mathrm{d}}$

\begin{tabular}{lll}
\hline$C_{\mathrm{f}}$ & $C_{\mathrm{d}}$ & Description \\
\hline$C_{\mathrm{f}}<1$ & $C_{\mathrm{d}}<7$ & Low degree of contamination \\
$1<C_{\mathrm{f}}<3$ & $7<C_{\mathrm{d}}<14$ & Moderate degree of contamination \\
$3<C_{\mathrm{f}}<6$ & $14<C_{\mathrm{d}}<28$ & Considerable degree of contamination \\
$C_{\mathrm{f}}>6$ & $C_{\mathrm{d}}>28$ & Very high degree of contamination \\
\hline
\end{tabular}

Table 8 Contamination categories based on $\mathrm{mC}_{\mathrm{d}}$ values

\begin{tabular}{ll}
\hline $\mathrm{mC}_{\mathrm{d}}$ & Description \\
\hline $\mathrm{mC}_{\mathrm{d}}<1.5$ & Zero to very low degree of contamination \\
$1.5<\mathrm{mC}_{\mathrm{d}}<2$ & Low degree of contamination \\
$2<\mathrm{mC}_{\mathrm{d}}<4$ & Moderate degree of contamination \\
$4<\mathrm{mC}_{\mathrm{d}}<8$ & High degree of contamination \\
$8<\mathrm{mC}_{\mathrm{d}}<16$ & Very high degree of contamination \\
$16<\mathrm{mC}_{\mathrm{d}}<32$ & Extremely high degree of contamination \\
$\mathrm{mC}_{\mathrm{d}} \geq 32$ & Ultra high degree of contamination \\
\hline
\end{tabular}

The highest value of contamination factor was recorded for $\mathrm{Cd}$ at station 4 . The $C_{\mathrm{f}}$ values are classified as low degree to a very high degree of contamination according to the Hakanson (1980) classification. All stations can be interpreted as a very high degree of contamination using $C_{\mathrm{d}}$ and high degree of contamination using $\mathrm{mC}_{\mathrm{d}}$ classification. According to Table 9, the highest values of PLI, $C_{\mathrm{d}}$ and $\mathrm{mC}_{\mathrm{d}}$ were recorded at station 4 . PLI ranged from 1.22 at station 3 to 1.55 at station 4 . Cluster analysis (CA) is a statistical method, which identifies the group of samples that behave similarly or show a significant relationship between different clusters. The result of cluster analysis is shown in the form of a dendrogram, which indicates the degree of similarity among compounds (Davis 1973; Karbassi et al. 2013; Beck et al. 2013).

The dendrogram resulting from UPGMA analysis showed four major clusters (Fig. 2). Result of cluster analysis for $\mathrm{Zn}$ and LOI shows that these two elements are related together by high similarity coefficient. As LOI in the environment is the index of biological activity, then $\mathrm{Zn}$ should have biological origin. The dendrogram also showed that a part of $\mathrm{Ca}$ and $\mathrm{Ni}$ is derived from lithogenous source as they are linked to $\mathrm{Fe}$. Altogether, presence of four different categories of heavy metals that are connected together with very low similarity coefficient indicates that there is not any relation between these four categories and also elements in them. 
Table 9 Metal contamination factors, degree of contamination, modified degree of contamination and pollution load index for each station

\begin{tabular}{|c|c|c|c|c|c|c|c|c|c|c|c|}
\hline \multicolumn{9}{|c|}{ Contamination factors $\left(C_{\mathrm{f}}\right)$ based on average shale content } & \multicolumn{3}{|c|}{ All elements } \\
\hline St & As & $\mathrm{Cd}$ & $\mathrm{Hg}$ & $\mathrm{Ni}$ & $\mathrm{Pb}$ & $\mathrm{Zn}$ & $\mathrm{Ca}$ & $\mathrm{Fe}$ & $C_{\mathrm{d}}$ & $\mathrm{mC}_{\mathrm{d}}$ & PLI \\
\hline 1 & 0.32 & 45.00 & 3.45 & 1.46 & 1.11 & 0.42 & 0.50 & 0.81 & 53.07 & 6.63 & 1.39 \\
\hline 2 & 0.25 & 32.23 & 3.77 & 1.26 & 0.87 & 0.84 & 0.41 & 0.94 & 40.58 & 5.07 & 1.35 \\
\hline 3 & 0.25 & 52.30 & 1.99 & 0.69 & 1.61 & 0.47 & 0.41 & 0.80 & 58.51 & 7.31 & 1.20 \\
\hline 4 & 0.39 & 55.50 & 3.91 & 1.09 & 0.92 & 0.92 & 0.51 & 0.89 & 64.14 & 8.02 & 1.56 \\
\hline 5 & 0.22 & 53.73 & 1.16 & 1.83 & 0.93 & 0.74 & 0.54 & 1.11 & 60.28 & 7.53 & 1.34 \\
\hline 6 & 0.28 & 45.37 & 3.07 & 1.32 & 1.08 & 0.60 & 0.45 & 0.96 & 53.13 & 6.64 & 1.40 \\
\hline Mean & 0.29 & 47.36 & 2.89 & 1.28 & 1.09 & 0.66 & 0.47 & 0.92 & 54.95 & 6.87 & 1.37 \\
\hline Max & 0.39 & 55.50 & 3.91 & 1.83 & 1.61 & 0.92 & 0.54 & 1.11 & 64.14 & 8.02 & 1.56 \\
\hline Min & 0.22 & 32.23 & 1.16 & 0.69 & 0.87 & 0.42 & 0.41 & 0.80 & 40.58 & 5.07 & 1.20 \\
\hline
\end{tabular}

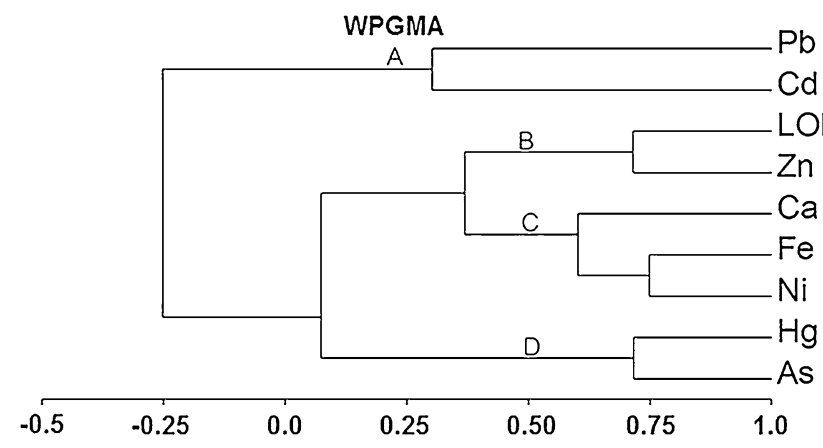

Fig. 2 Dendrogram showing clustering of metals and LOI

\section{Conclusion}

The intensity of pollution at the studied area was evaluated using enrichment factor (EF), geo-accumulation index $\left(I_{\text {geo }}\right)$, pollution index $\left(I_{\text {poll }}\right)$, contamination factor $\left(C_{\mathrm{f}}\right)$, modified degree of contamination $\left(\mathrm{mC}_{\mathrm{d}}\right)$ and pollution load index (PLI) for $(\mathrm{Ca}, \mathrm{Fe}, \mathrm{Ni}, \mathrm{Cd}, \mathrm{Pb}, \mathrm{Zn}, \mathrm{AS}, \mathrm{Hg}$ ) in fine fraction sediments collected from 6 stations in Bamdezh wetland, Iran. Also, the chemical sequential extractions were employed for determination of the anthropogenic portions of metals. The heavy metal concentration in the sediments was described in the descending order of $\mathrm{Fe}>\mathrm{Ca}>\mathrm{Ni}>\mathrm{Zn}>\mathrm{Pb}>\mathrm{Cd}>\mathrm{As}>\mathrm{Hg}$. The results of partition studies revealed the arrangement of anthropogenic portions for the metals as follows: $\mathrm{Cd}(86 \%)>\mathrm{Pb}$ $(80 \%)>\mathrm{Ni}(46 \%)>\mathrm{Zn}(44 \%)>\mathrm{Fe}(24 \%)$. The mean enrichment factor values for various metals were between minimal enrichment and extremely enrichment. The maximum mean $\mathrm{EF}$ value belongs to $\mathrm{Cd}(\mathrm{Cd}=45.55)$ indicating extremely enrichment, and also, the minimum mean $\mathrm{EF}$ value is seen for As (As = 0.28) showing minimal enrichment. The results show the limitation of $I_{\text {geo }}$ index in the assessment of pollution. The values obtained from $I_{\text {poll }}$ index are indicative of a broad range (from unpolluted to moderately polluted to moderately to strongly polluted) for various studied elements.

The highest value of contamination factor was recorded for $\mathrm{Cd}$ at station 4 . The $C_{\mathrm{f}}$ values are classified as low degree to a very high degree of contamination. All stations can be interpreted as a very high degree of contamination using $C_{\mathrm{d}}$ and high degree of contamination using $\mathrm{mC}_{\mathrm{d}}$ classification. The highest values of PLI, $C_{\mathrm{d}}$ and $\mathrm{mC}_{\mathrm{d}}$ were recorded at station 4 . PLI ranged from 1.22 at station 3 to 1.55 at station 4.

Result of cluster analysis for $\mathrm{Zn}$ and LOI shows that these two elements are related together by high similarity coefficient. As LOI in the environment is the index of biological activity, then $\mathrm{Zn}$ should have biological origin. The dendrogram also showed that a part of $\mathrm{Ca}$ and $\mathrm{Ni}$ is derived from lithogenous source as they are linked to Fe. Altogether, presence of four different categories of heavy metals that are connected together with very low similarity coefficient indicates that there is not any relation between these four categories and also elements in them.

Acknowledgments We thank Dr. Behnoush Aminzadeh from wet chemical laboratory of Graduate Faculty of Environment (University of Tehran) for chemical analysis. We also thank Mr. Amin Bagherzadeh who assisted us in collection of samples.

\section{References}

Abrahim GMS, Parker RJ (2008) Assessment of heavy metal enrichment factors and the degree of contamination in marine sediments from Tamaki Estuary, Auckland. N Z Environ Monit Assess 136(1-3):227-238

Adjey-Boateng D, Obirikorang KA, Amisah S (2010) Bioaccumulation of heavy metals in the tissue of the clam galatea paradoxa and sediments from the Volta Estuary Ghana. Int J Environ Res 4(3):533-540

Ahmed MK, Islam S, Rahman S, Haque MR, Islam MM (2010) Heavy metals in water, sediment and some fishes of Buriganga River, Bangladesh. Int J Environ Res 4(2):321-332 
Al-Juboury AI (2009) Natural pollution by some heavy metals in the Tigris River, Northern Iraq. Int J Environ Res 3(2):189-198

Beck M, Böning P, Schückel U, Stiehl T, Schnetger B et al (2013) Consistent assessment of trace metal contamination in surface sediments and suspended particulate matter: a case study from the Jade Bay in NW Germany. Mar Pollut Bull 70:100-111

Bostanzadeh M (2003) Water and pollution management of Bamdezh wetland (Persian). MSc Thesis of Azad University, Science and research branch of Ahvaz

Bowen HJM (1979) Environmental chemistry of the elements. Academic Press, London 333

Buat-Menard P, Chesselet R (1979) Variable influence of the atmospheric flux on the trace metal chemistry of oceanic suspended matter. Earth Planet Sci Lett 42(3):399-411

Davis (1973) Wie statistics and data analysis in geology. Wiley, New York

Elsokkary IH, Müller G (1990) Assessment and speciation of chromium, nickel, lead, and cadmium in the sediments of the river Nile Egypt. Sci Total Environ 97(98):455-463

Förstner U, Wittmann GTW (1981) Metal pollution in the aquatic environment ( $2 \mathrm{nd}$ rev ed.). Springer, Berlin

Hakanson L (1980) An ecological risk index for aquatic pollution control. A sedimentological approach. Water Res 14(8):975-1001

Jamee M (2002) (Persian) introduction wetlands of Khuzestan. Research of research office of KWPA

Karbassi AR, Monavari SM, Nabi Bidhendi GR, Nouri J, Nematpour K (2008) Metal pollution assessment of sediment and water in the Shur River. Environ Monit Assess 147(1-3):107-116

Karbassi AR, Heidari M, Vaezi AR, Valikhani Samani AR, Fakhraee M, Heidari F (2013) Effect of pH and salinity on flocculation process of heavy metals during mixing of Aras River water with Caspian Sea water. Environ Earth Sci 72(2):457-465

Karbassi AR, Fakhraee M, Heidari M, Vaezi AR, Valikhani Samani AR (2014) Dissolved and particulate trace metal geochemistry during mixing of Karganrud River with Caspian Sea water. Arab J Geosci. doi:10.1007/s12517-014-1267-4

Lee JN, Mohamed CAR (2009) Trace metal contents in the porites corals of Peninsular Malaysia. Int J Environ Res 3(1):85-94

Muller G (1979) Schwermetalle in den Sedimenten des Rheins Veranderungenseit. Umschau 79(24):778-783

Nasehi F, Hassani AH, Monavvari M, Karbassi AR, Khorasani N (2012) Evaluating the metallic pollution of riverine water and sediments: a case study of Aras River. Environ Monit Assess 185(1):197-203

Nemr A, Sikaily A, Khaled A (2007) Total and leachable heavy metals in muddy and sandy sediments of Egyptian Coast along Mediterranean Sea. Environ Monit Assess 129(1-3):151-168
Rafiei B, Bakhtiari Nejad M, Hashemi M, Khodaei AS (2010) Distribution of heavy metals around the Dashkasan Au Mine. Int J Environ Res 4(4):647-654

Sinem Atgin R, El-Agha O, Zararsız A, Kocataş A, Parlak H, Tuncel $\mathrm{G}$ (2000) Investigation of the sediment pollution in Izmir Bay: trace elements. Spectrochim Acta Part B 55(7):1151-1164

Sundararajan M, Natesan U (2010) Geochemistry of elements in core sediments near point Claimere, the Southeast Coast of India. Int J Environ Res 4(3):379-394

Sutherland RA (2000) Bed sediment-associated trace metals in an urban stream, Oahu Hawaii. Environ Geol 39(6):611-627

Szefer P, Szefer K, Glasby GP, Pempkowiak J, Kaliszan R (1996) Heavy-metal pollution in surficial sediments from the Southern Baltic sea off Poland. J Environ Sci Health. Part A Environ Sci Eng Toxicol 31(10):2723-2754

Tessier A, Campbell PG, Bisson M (1979) Sequential extraction procedure for the speciation of particulate trace metals. Anal Chem 51(7):844-851

Tomlinson DL, Wilson JG, Harris CR, Jeffrey DW (1980) Problems in the assessment of heavy-metal levels in estuaries and the formation of a pollution index. Helgol Meeresunters 33(1-4):566-575

Uba S, Uzairu A, Okunola OJ (2009) Content of Heavy metals in lumbricus terrestris and associated soils in dump sites. Int $\mathrm{J}$ Environ Res 3(3):353-358

Vaezi AR, Karbassi AR, Fakhraee M, Valikhani Samani AR, Heidari M (2014) Assessment of sources and concentration of metal contaminants in marine sediments of Musa estuary, Persian Gulf. J Environ Stud 40:345-360

Valikhani Samani AR, Karbassi AR, Fakhraee M, Heidari M, Vaezi AR, Valikhani Z (2014) Effect of dissolved organic carbon and salinity on flocculation process of heavy metals during mixing of the Navrud River water with Caspian Seawater. Desalin Water Treat. doi:10.1080/19443994.2014.920730

Venugopal T, Giridharan L, Jayaprakash M (2009) Characterization and risk assessment studies of bed sediments of river Adyar-an application of speciation study. Int J Environ Res 3(4):581-598

Zhang L, Ye X, Feng H, Jing Y, Ouyang T, Yu X et al (2007) Heavy metal contamination in western Xiamen Bay sediments and its vicinity China. Mar Pollut Bull 54(7):974-982

Zhuang W, Gao X (2014) Integrated Assessment of Heavy Metal Pollution in the Surface Sediments of the Laizhou Bay and the Coastal Waters of the Zhangzi Island, China: comparison among Typical Marine Sediment Quality Indices. PLoS One 9(4):e94145 